\title{
ANOMALOUS PULMONARY VENOUS DRAINAGE BY
}

\author{
ALAN R. MUIR \\ From the Department of Anatomy, University of Edinburgh
}

(RECEIVED FOR PUBLICATION MAY 20, 1952)

Cases of drainage of the pulmonary veins into the right side of the heart have been well summarized by Brody (1942). He reported 38 cases of complete, and 68 cases of partial, drainage of the pulmonary veins into the right atrium or its tributaries.

The purpose of this paper is to record a further case, and to summarize the cases not reported by Brody and those which have been reported during the last 10 years. With the development of thoracic surgery, angiocardiography, and cardiac catheterization during recent years these cases now have some clinical importance apart from their anatomical interest.

\section{CASE REPORT}

The cadaver was that of a muscular man aged 66 . The heart was large but within normal limits considering the degree of muscular development. The interatrial septum was closed, and there were no cardiac abnormalities. An upper, larger, and a lower, smaller, pulmonary vein arose from the anterior part of the upper lobe of the right lung. These two veins joined into a very short, broad common trunk which opened into the superior vena cava, inferior and anterior to the opening of the azygos vein (Fig. 1). A large, lower, right pulmonary vein passed into the left atrium, and the drainage of the left lung was normal. The cause of death was not known, but there was no evidence that it was due to any cardiac or respiratory disease.

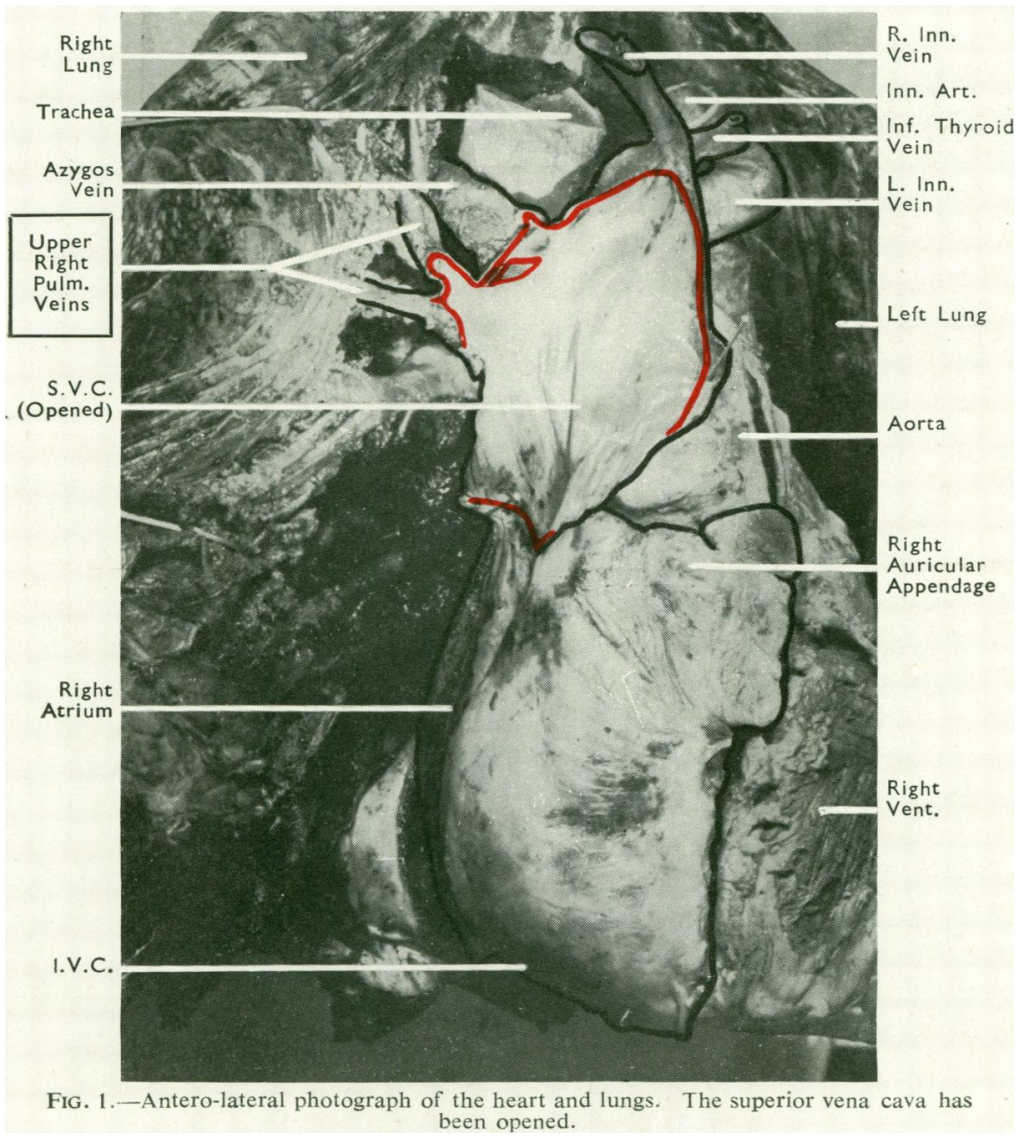

Discussion

A study of the cases reported by Brody and the cases in Tables I, IIA, and IIB reveals that there is a sharp division into two types; the first of complete anomalous drainage with or without associated cardiac anomalies, which rarely survive early childhood; the second group showing partially anomalous drainage which survive to adult life and have been discovered by post-mortem examination, as an operative finding, or by angiocardiography. It is therefore this latter group which will be of greater importance and interest to clinicians.

Compere and Forsyth (1944) state that if $75 \%$ of the pulmonary blood is returned to the left atrium there will be no cardio-respiratory symptoms. Their statement would appear to be supported by the present case and by the recent cases reported in the literature. From a scrutiny of Table I of this paper and the tables in Brody's 
TABLE I

INCOMPLETE DRAINAGE OF THE PULMONARY VEINS INTO THE RIGHT ATRIUM OR ITS TRIBUTARIES

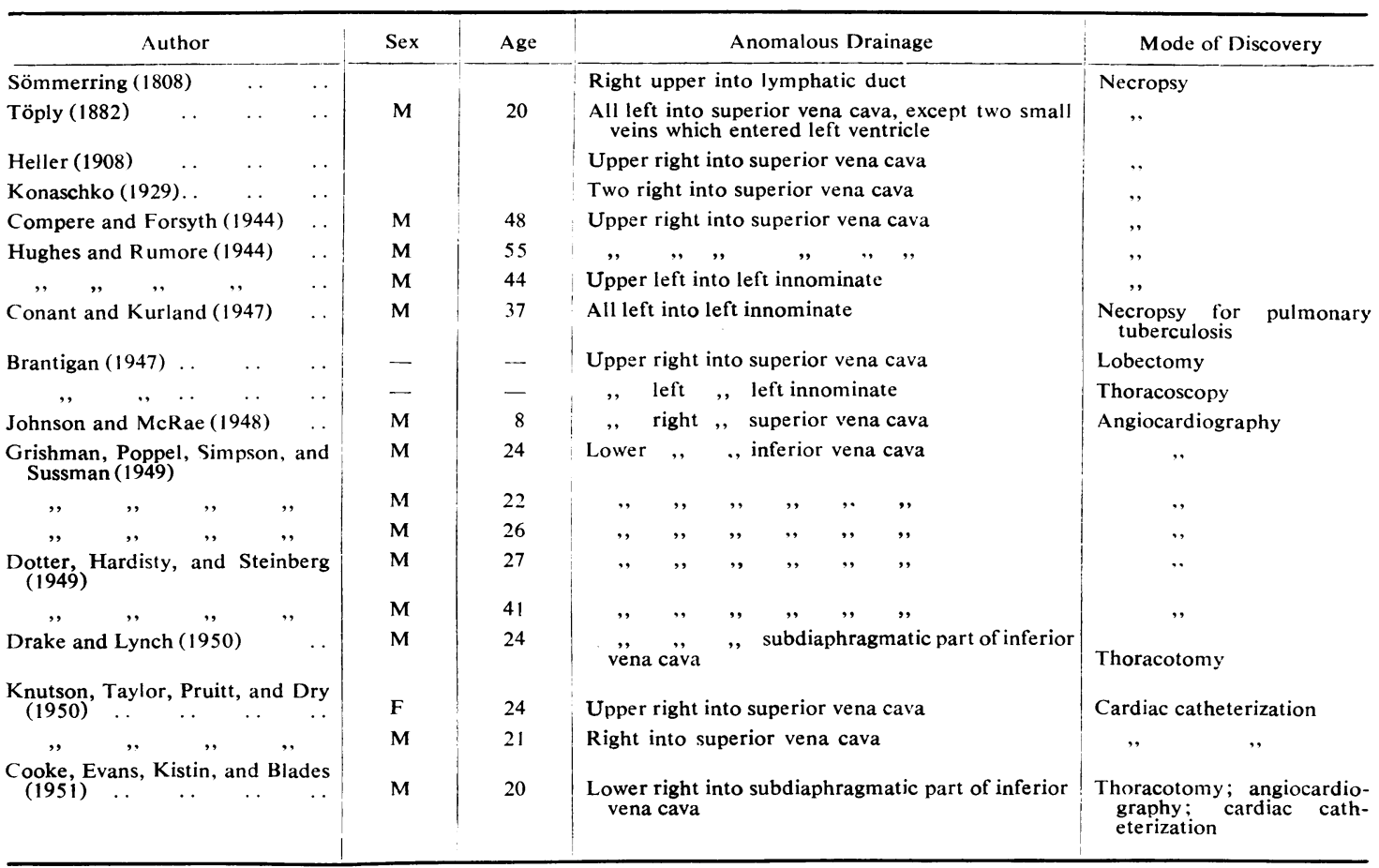

TABLE IIA

TOTAL DRAINAGE OF THE PULMONARY VEINS INTO THE RIGHT ATRIUM OR ITS TRIBUTARIES WITHOUT OTHER MAJOR CARDIAC ABNORMALITIES

\begin{tabular}{|c|c|c|c|c|c|c|c|c|}
\hline \multicolumn{3}{|l|}{ Author } & Sex & Age & Site of Anomalous Drainage & \multicolumn{3}{|c|}{ Comment } \\
\hline \multicolumn{3}{|c|}{$\begin{array}{l}\text { Conn, Calder, MacGregor, and } \\
\text { Shaner (1942) }\end{array}$} & 一 & 7 days & Through a common trunk into superior vena cava & \multicolumn{3}{|c|}{ Patent foramen ovale } \\
\hline Kernan (1944) & . & . & $\mathbf{M}$ & $4 \mathrm{mths}$ & $\begin{array}{l}\text { Through a persistent left superior vena cava to left } \\
\text { innominate and hence to (right) superior vena cava }\end{array}$ & , & ", & . \\
\hline Graham, P. M. (1944) & . & $\ldots$ & $\mathbf{F}$ & 8, & Through a common trunk into right atrium & , & ,, &. \\
\hline Taussig (1947) & $\ldots$ & $\cdots$ & $\mathbf{M}$ & 8, & Coronary sinus & .. & , & , \\
\hline ,, , , & $\cdots$ & . & $\mathrm{F}$ & 4 years & $\begin{array}{l}\text { Through a persistent left superior vena cava to left } \\
\text { innominate and hence to (right) superior vena cava }\end{array}$ & , & , & , \\
\hline Mykschowszky (1948) & $\ldots$ & $\ldots$ & $\mathbf{M}$ & 18 days & $\begin{array}{l}\text { Through a common trunk which perforated the } \\
\text { diaphragm with the oesophagus and opened into } \\
\text { the ductus venosus }\end{array}$ & & & \\
\hline Vass and Mack (1949) & . & . & $\mathbf{F}$ & $19 \mathrm{mths}$ & Coronary sinus & ,, & , , & , , \\
\hline Edwards and DuShane & $(1950)$ & $\ldots$ & $\mathbf{M}$ & 6 days & $\begin{array}{l}\text { Through a common trunk which perforated the } \\
\text { diaphragm with the oesophagus and opened into } \\
\text { the ductus venosus }\end{array}$ & $\begin{array}{l}\text { Pater } \\
\text { sia }\end{array}$ & fora & $\begin{array}{l}\text { ovale; atre- } \\
\text { of the heart }\end{array}$ \\
\hline Butler (1952) & $\cdots$ & $\cdots$ & 一 & - & $\begin{array}{l}\text { Through a common trunk which perforated the } \\
\text { diaphragm through a separate foramen and } \\
\text { opened into the left branch of the portal vein, } \\
\text { immediateiy to the left of the opening of a patent } \\
\text { ductus venosus }\end{array}$ & Pater & forat & ovale \\
\hline $\begin{array}{l}\text { Edwards, DuShane, Al } \\
\text { Burchell (1951) }\end{array}$ & cott, an & & $\mathbf{M}$ & 7 weeks & $\begin{array}{l}\text { Through a common dilated sac into the superior } \\
\text { vena cava }\end{array}$ &, & , & 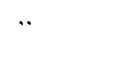 \\
\hline
\end{tabular}


TABLE IIB

TOTAL DRAINAGE OF THE PULMONARY VEINS INTO THE RIGHT ATRIUM OR ITS TRIBUTARIES ASSOCIATED WITH OTHER MAJOR CARDIAC ABNORMALITIES

\begin{tabular}{|c|c|c|c|c|c|c|c|}
\hline \multicolumn{4}{|c|}{ Author } & \multirow{2}{*}{$\frac{\text { Sex }}{M}$} & \multirow{2}{*}{$\frac{\text { Age }}{15 \mathrm{mths}}$} & Site of Anomalous Drainage & Associated Anomalies \\
\hline Turner (1882) & . & . & $\cdots$ & & & (Left) superior vena cava & $\begin{array}{l}\text { Patent foramen ovale; patent } \\
\text { ductus; cor biloculare }\end{array}$ \\
\hline Michaelsohn (192 & & $\cdots$ & $\cdots$ & $\mathbf{M}$ & 21 years & , , , & Cor biloculare; situs inversus \\
\hline McIntosh (1926) & . & $\cdots$ & $\cdots$ & $\mathbf{M}$ & 6 mths & $\begin{array}{l}\text { Upper right to superior vena cava; left atrium } \\
\text { drained by a vein to the superior vena cava }\end{array}$ & $\begin{array}{l}\text { Mitral atresia; absent inter- } \\
\text { ventricular septum; patent } \\
\text { ductus }\end{array}$ \\
\hline Hu (1929) & $\cdots$ & $\cdots$ & . & $\mathbf{M}$ & 7 , & Through a common trunk to left gastric vein & Situs inversus \\
\hline \multicolumn{3}{|c|}{ Barge and van Oijen (1932) } & $\cdots$ & & & $\begin{array}{l}\text { Upper right to superior vena cava; rest to inferior } \\
\text { vena cava }\end{array}$ & \\
\hline Ingalls (1932) & . & $\cdots$ & $\cdots$ & $\mathbf{F}$ & 2, & $\begin{array}{l}\text { Through a persistent left superior vena cava to left } \\
\text { innominate and hence to (right) superior vena cava }\end{array}$ & Dextrocardia \\
\hline \multicolumn{3}{|c|}{ Feldman and Chalmers (1933) } & $\cdots$ & $\mathbf{M}$ & $1 \mathrm{mth}$ & $\begin{array}{l}\text { The four pulmonary veins opened separately into } \\
\text { right atrium }\end{array}$ & $\begin{array}{l}\text { Transposition of great ves- } \\
\text { sels; patent foramen ovale }\end{array}$ \\
\hline \multicolumn{3}{|c|}{ Goltman and Stern (1939) } & $\cdots$ & $\mathbf{M}$ & $14 \mathrm{mths}$ & $\begin{array}{l}\text { Through a persistent left superior vena cava to left } \\
\text { innominate and hence to (right) superior vena cava }\end{array}$ & $\begin{array}{l}\text { Situs inversus; persistent } \\
\text { truncus }\end{array}$ \\
\hline Young (1947) & . & . & . & - & Stillborn & $\begin{array}{l}\text { Through a common trunk which perforated the } \\
\text { diaphragm anterior to oesophagus and opened } \\
\text { into portal vein }\end{array}$ & Cor biloculare \\
\hline Howald (1949) & . & $\cdots$ & $\cdots$ & & 2, & Superior vena cava & \\
\hline ", & * & $\cdots$ & $\cdots$ & & 6, & Hepatic veins & \\
\hline \multicolumn{3}{|c|}{ Mehn and Hirsch (1947) } & $\cdots$ & $\mathbf{M}$ & 12 days & Ductus venosus & Multiple anomalies \\
\hline \multicolumn{3}{|c|}{ Weinberg and Ko!son (1949) } & $\cdots$ & $\mathbf{M}$ & 6, & Through a common trunk into portal vein & $\begin{array}{l}\text { Patent interventricular sep- } \\
\text { tum; persistent truncus }\end{array}$ \\
\hline \multicolumn{4}{|c|}{ Edwards and DuShane (1950) } & $\mathbf{M}$ & 21, & $\begin{array}{l}\text { Through a vein which connects the left atrium to } \\
\text { to the left innominate vein }\end{array}$ & $\begin{array}{l}\text { Patent interventricular } \\
\text { septum }\end{array}$ \\
\hline
\end{tabular}

paper it can be seen that it is rare for one lung to be drained to the left atrium while the other lung possesses complete anomalous drainage to the right atrium. As Brantigan (1947) points out, this is a comforting observation to thoracic surgeons performing pneumonectomy.

Including the present case, there have been reports of 151 cases of anomalous drainage into the right side of the heart; of these, 62 cases have exhibited complete anomalous drainage and 89 have been partially anomalous. A summary of this latter group is given below :

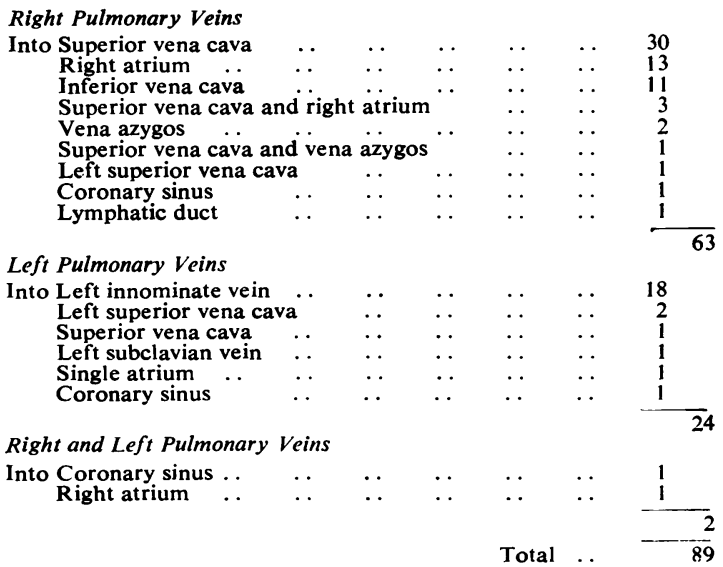

EMbryological Basis for the ANOMALIES.The development of the pulmonary veins has been studied by Brown (1913) in the cat, and more recently by Auër (1948) in man ; these papers can be consulted for further references on this subject.

The primitive fore-gut, including the developing lung buds, is surrounded by a plexus of thinwalled vessels which communicate with the cardinal (systemic) veins. About the $3 \mathrm{~mm}$. stage several evaginations are said to arise from the dorsal wail of the venous end of the heart tube ; these evaginations establish connexions with the splanchnic plexus. The common pulmonary vein is normally formed from the most cephalic of these connexions between the venous end of the heart and the splanchnic plexus. The opening of the common pulmonary vein, originally median in position, is subsequently displaced to the left side of the future interatrial septum. Especially in those papers in which the original evaginations are said to arise from the sinus venosus it is not clear how this displacement occurs (Davies and MacConaill, 1937 ; Brown, 1913). The single pulmonary vein is subsequently absorbed until there are four openings into the heart.

From this short account it can be seen that if other connexions of the splanchnic plexus persist, either partial or complete anomalous pulmonary drainage will result. 


\begin{tabular}{|c|c|}
\hline $\begin{array}{l}\text { Anomalous Drainage } \\
\text { Into }\end{array}$ & Embryo'ogical Explanation \\
\hline 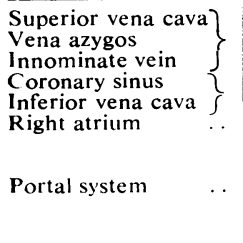 & $\begin{array}{l}\text { Persistence of the connexion between the } \\
\text { splanchnic plexus and the cardinal veins } \\
\text { Persistence of the more caudal evaginations } \\
\text { Failure of the common pulmonary vein to } \\
\text { be displaced to the left of the interatrial } \\
\text { septum } \\
\text { Persistence of the connexion between the } \\
\text { splanchnic plexus and the plexus of veins } \\
\text { around the mid-gut }\end{array}$ \\
\hline
\end{tabular}

Owing to the fact that the total number of specimens examined cannot be determined, it is impossible to give any estimation of the frequency of these anomalies. But the number of cases recorded has increased in recent years with the increase in the necessary examinations, and it can be concluded that these anomalies should not be regarded as rare. The possibility of anomalous pulmonary venous drainage should be considered during cardiac catheterization, angiocardiography, and in intrathoracic surgery.

\section{REFERENCFS}

Auër, J. (1948). Anat. Rec., 101, 581.

Barge, J. A. J., and van Oijen, A. (1932). Z. Anat. EntwGesch. 98, 760 .

Brantigan, O. C. (1947). Surg. Gynec. Obstet., 84, 653.

Brody, H. (1942). Arch. Path. Lab. Med., 33, 221

Brown, A. J. (1913). Anat. Rec., 7, 299.
Butler, H. (1952). J. Anat., Lond., 86, 485.

Compere, D. E., and Forsyth, H. F. (1944). J. thorac. Surg., 13, 63. Conant, J. S., and Kurland, L. T. (1947). Ibid. 16, 422.

Conn, L. C., Calder, J., MacGregor, J. W., and Shaner, R. F. (1942). Anat. Rec., 83, 335

Cooke, F. N., Evans, J. M., Kistin, A. D., and Blades, B. (1951). $J$ thorac. Surg., 21, 452 .

Davies, F., and MacConaill, M. A. (1937). J. Anat., Lond., 71, 437.
Dotter, C. T., Hardisty, N. M., and Steinberg, I. (1949). Amer. J. med. Sci., 218, 31 .
m. M., and Steinberg, I. (1949). Amer.
. I . (1950). J. thorac. Surg., 19. 433.

Drake, E. H., and Lynch, J. P. (1950). J. thorac. Surg., 19, 433.

Edwards, J. E., and DuShane, J. W. (1950).
49, 517 . 49, 51 Alcott, D. L., and Burchell, H. B. (1951). Ibid., 51, 446. Feldman, W M., and Chalmers, A. (1933). Brit.J. Child. Dis., 30, 27 Goltman, D. W., and Stern, N.S. (1939). Amer. Heart J., 18, 176.

Goltman, D. W., and Stern, N. S. (1939). Amer
Graham, P. M. (1944). Med.J. Aust., 2, 545.

Grishman, A., Poppel, M. H., Simpson, R. S., and Sussman, M. L. (1949). Amer. J. Roentgenol..62, 500.

Heller, A. (1908). Verh. dtsch. paih. Ges., 12, 248.

Howald, E. (1949). Helv. paediat. Acta, 4, 322.

Hu, C. H. (1929). Amer. J. Path., 5, 389

Hughes, C W., and Rumore, P. C (1944). Arch. Path Lab. Med. 37, 364 .

Ingalls, N. W. (1932). Anat. Rec., 53, 269.

Johnson, A. L., and McRae, D. L.. (1948). Pediatrics, 2, 643

Kernan, J. D. (1944). Ann. Otol., St. Louis, 53, 818.

Knutson, J. R. B., Taylor, B. E., Pruitt, R. O., and Dry, T. J. (1950). Proc. Mayo Clin., 25, 52.

Konaschko. P. I. (1929). Z. Anat. EntwGesch., 89, 672.

McIntosh, C. A. (1926). Amer. Heart J., 1,735.

Melntosh, C. A. (1926). Amer. Heart J., 1, 735. Path, 23, 125

Mehn, W. H., and Hirsch, F. E. (1947). Amer.J. Path. 23, 125. Hughes and Rumore.

Mykschowszky, G. (1948). Klin. Med., 3, 263.

Sömmerring, S. T. (1808). Cited by Hughes and Rumore.

Taussig, H. B. (1947). Congenital Nalformations of the Heart. The Commonwealth Fund, New York.

Töply, R. (1882). Prag. med.Wschr.,7, 223. Cited by Hughes and Rumore.

Turner, - (1882). Lancet, 2, 1034.

Vass, A., and Mack, J. K. (1949). Amer. J. Child. Dis., 78, 906

Weinherg, T., and Kolson, J. W. (1949). Bull. int. Ass. med. Mus. 30,68 .

Young, M. O. (1947). Arch. Path. Lab. Med., 44, 169. 